\title{
Efficacy of tank mixtures of post-emergence herbicides in common bean
}

Júlia Carvalho Costa ${ }^{1}$

Silvino Guimarães Moreira²

Antonio Henrique Fonseca de Carvalho 3

Guilherme Vieira Pimentel 4

Diego Rafael Quispe Torres 5

Junior Cézar Resende Silva ${ }^{6}$

\section{Abstract}

In common bean, the occurrence of weeds can cause significant reductions in the final grain yield. This study aimed to evaluate the efficiency of different herbicide trials, applied individually or in a mixture, in the management of common bean weeds. A randomized complete block was used, arranged in subdivided plots. The main plots consisted of three types of beans (Carioca Pérola cultivar, Black cultivar IPR Tuiuiu and one Red Bean strain VR20) and the subplots of different control modes, in four replications: hand weeding, fomesafen (250 g per hectare of ingredient active ( $\mathrm{g} \mathrm{ha}^{-1}$ of a.i.)), fomesafen (375 $\mathrm{g}$ ha-1 of a.i.), imazamox + bentazon $\left(0,23+0,6 \mathrm{~g}\right.$ ha $^{-1}$ of a.i.), imazamox + bentazon + fomesafen $\left(0.23+0.6+125 \mathrm{~g} \mathrm{ha}^{-1}\right.$ of a.i. $)$ and imazamox + bentazon + fomesafen $\left(0.23+0.6+83 \mathrm{~g} \mathrm{ha}^{-1}\right.$ of a.i.). The following traits were evaluated during three seasons: weeds present in the area, phytotoxicity symptoms, and common bean grain yield. The data were analyzed using a variance analysis ( $F$ test), the means obtained were grouped by the Scott Knott test at $5 \%$ probability. Differences in grain yield performance were observed between cultivars and crops season due to herbicide application. The most efficacy treatment for weeds was imazamox + bentazon + fomesafen $\left(230+600+125 \mathrm{~g} \mathrm{ha}^{-1}\right.$ of a.i.), resulting in improved control and greater efficiency in avoiding grain yield losses.

Keywords: Chemical control. Phaseolus vulgaris. Grain Yield. Phytotoxicity. Weed.

\section{Introduction}

The common bean (Phaseolus vulgaris L.) adapts to the diverse soil and climatic conditions of Brazil. Currently, weed interference is considered one of the most influential factors in reducing common bean yields in all growing seasons (BORCHARDTT et al., 2011; LAMEGO et al., 2011).

One of the major problems in controlling weeds in common bean (Phaseolus vulgaris L.) is the lacking availability of products the effective control of broadleaf weeds (dicotyledons) have been

1 Universidade Federal de Lavras- UFLA. Mestranda em Fitotecnia. juliacarvalhocos@gmail.com. Campus Universitário, Caixa Postal: 3037, Lavras/MG, Brasil, 37200-000.

2 UFLA. Professor. silvino.moreiraufla@gmail.com.

3 UFLA. Mestrando em Fitotecnia. antonio.carvalho@dag.ufla.br.

4 UFLA. Professor. guilherme.pimentel@ufla.br.

5 UFLA. Mestrando em Fitotecnia. rafo.qtorres@gmail.com.

6 UFLA. Mestrando em fitotecnia. resendejunior62@gmail.com. 
released in recent years (MANCUSO et al., 2016). Herbicide Amplo ${ }^{\circledR}$ (bentazon + imazamox), one of the most used in the crop for broadleaf weed control, was released more than 10 years ago.

Due to the absence of new products, combinations of herbicides with pre and post-emergence action with different modes of action have been used to improve the levels of weed control (BRESSANIN et al., 2015). The combination of these products contributes to reduce selection pressure and diminish new cases of resistant plants (GALON et al., 2016).

Currently, 27 active ingredients are registered for weed control in beans in Brazil, three of which are applied before sowing or emergence, and 24 for post-emergence application. Nevertheless, only 7 of the active ingredients for a post-emergence application can control broadleaf weeds (dicotyledons), and 11 can control grass weeds (monocotyledons) (AGROFIT, 2018).

Although 11 active ingredients can control grass weeds in common bean, they all have the same mode of action. It is therefore difficult to rotate the mechanisms of action, as recommended in the literature. According to Weed Science (2018), these herbicides are ACCase (acetyl-CoA carboxylase) inhibitors and can be divided into two chemical groups oxime cyclohexanedione (DIMs) and aryloxyphenoxypropionic acid (FOPs).

Broadleaf weeds can be controlled by three products (imazamox, imazapyr, and imazethapyr) whose mechanism of action is the inhibition of ALS (acetolactate synthase), of the Imidazolinone group. Three other products inhibit PROTOX (protoporphyrinogen oxidase), i.e., fomesafen, acifluorfen-sodium, and acifluorfen, of which fomesafen is also recommended for pre-emergence weed management. Lastly, bentazon, whose mechanism of action is the inhibition of photosystem II (PSII) (MANCUSO et al., 2016).

While some studies described efficient weed control by some products such as fomesafen (BARCELLOS JÚNIOR et al., 2016), imazamox + bentazon (SILVA et al., 2013), other studies reported undesirable injury in common bean. The latter products can compromise grain yield (FREITAS et al., 2009; MANABE et al., 2015; OLIVEIRA et al., 2013). Also, most studies were performed with old cultivars no longer used in the current production systems. It is believed that there may be differences in sensitivity of the current cultivars to isolated molecules, as well as in the mixtures of the same, calling for further studies.

Another important factor was the permission to mix products in tanks in Brazil in 2019. Consequently, studies are required to test the efficacy of weed control as well as the potential phytotoxicity to the current cultivars of these blends. This study assessed the weed control efficacy and phytotoxicity of separate or combined herbicides for common bean cultivars, as well as the effect on yield-related traits of the grain classes carioca, black, and red.

\section{Material and methods}

The experiment was installed at the Muquem Farm of the Federal University of Lavras (UFLA), in Lavras, MG, during the growing seasons 2016 and 2017. The geographical coordinates of the farm are latitude $21^{\circ} 14^{\prime} \mathrm{S}$, longitude $45^{\circ} 00^{\prime} \mathrm{W}$, and altitude $918 \mathrm{~m}$.

The climate in the county of Lavras has well-defined seasons, with a dry season from April to September and a rainy one from October to March, and is classified as Cwa, according to Köppen climate classification. The average annual temperature is around $20.4{ }^{\circ} \mathrm{C}$, with means of $22.8^{\circ} \mathrm{C}$ and $17.1{ }^{\circ} \mathrm{C}$, respectively, in the hottest and coldest month. The annual precipitation is $1,460.0 \mathrm{~mm}$, the total annual evaporation $1,034.3 \mathrm{~mm}$ and the mean annual relative humidity $76 \%$. The mean maximum and minimum temperatures and average monthly rainfall (FIGURE 1) and other data were provided by the Meteorological Station of Lavras. 
Figure 1 - Diagram of the mean rainfall and maximum and minimum monthly temperatures in Lavras in 2016, 2017, and 2018.

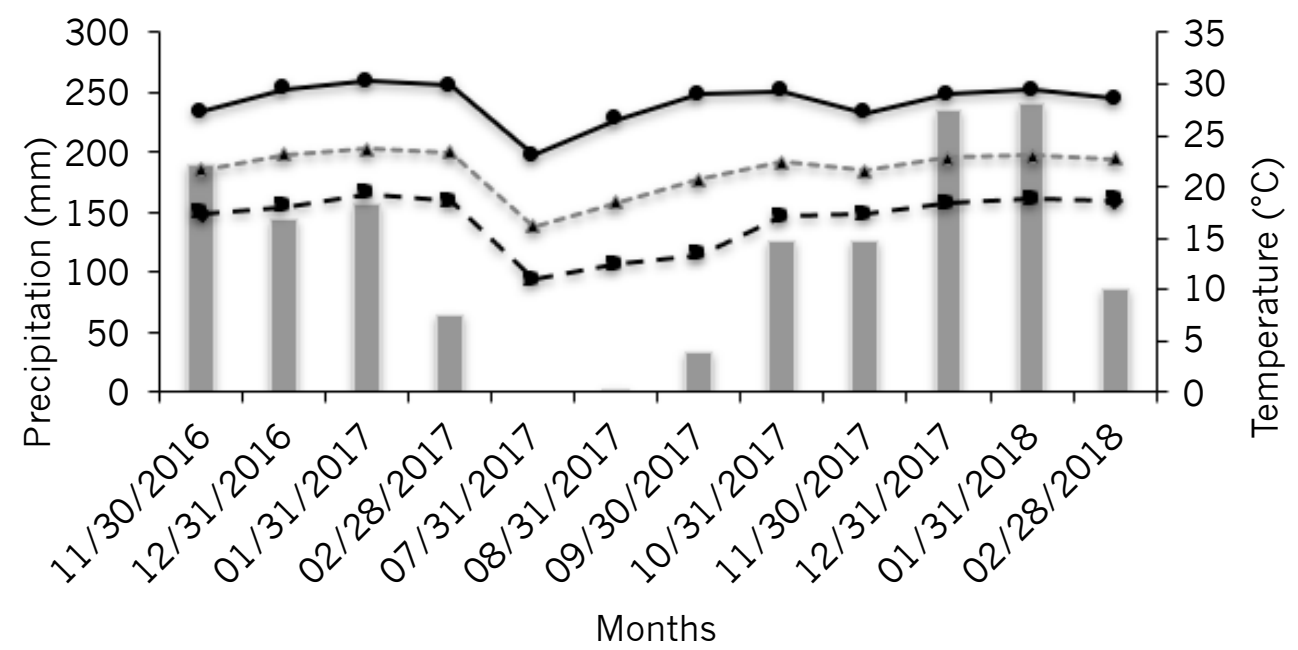

Precipitation $(\mathrm{mm}) \leftarrow \rightarrow \mathrm{T}^{\circ} \mathrm{C}$ minimum $--\star--\mathrm{T}^{\circ} \mathrm{C}$ mean $\longrightarrow \mathrm{T}^{\circ} \mathrm{C}$ maximum

Source: Instituto Nacional de Meteorologia (2018).

The soil of the experimental area is the Oxysol, and the soil chemical properties of the area before the experiments are shown in Table 1.

Table 1 -Summary of the soil chemical analysis of the experimental areas in Lavras/MG, at a soil depth of 0-20 cm, in the growing seasons 2016/2017 and 2017/2018.

\begin{tabular}{|c|c|c|c|c|c|c|c|c|c|c|}
\hline \multirow{2}{*}{ Growing season } & $\mathrm{pH}$ & $\mathbf{P}^{(1)}$ & $\mathrm{K}$ & $\mathrm{Ca}$ & $\mathrm{Mg}$ & $\mathrm{Al}$ & $\mathrm{H}+\mathrm{Al}$ & SB & $T$ & V \\
\hline & $\mathrm{H}_{2} \mathrm{O}$ & \multicolumn{2}{|c|}{$\mathrm{mg} \mathrm{dm}^{-3}$} & \multicolumn{6}{|c|}{ - $\mathrm{cmol}_{\mathrm{c}} \mathrm{dm}^{-3}$} & $\%$ \\
\hline 16/17 rainy & 5,8 & 10,1 & 81 & 2,5 & 0,5 & 0,5 & 3,3 & 3,1 & 6,4 & 49 \\
\hline 16/17 winter & 5,9 & 23,1 & 142 & 3,8 & 0,8 & 0,1 & 3,4 & 3,9 & 8,3 & 59 \\
\hline $17 / 18$ rainy & 5,7 & 8,70 & 153 & 2,9 & 0,8 & 0 & 4,1 & 4,1 & 8,2 & 50 \\
\hline
\end{tabular}

$\mathrm{SB}=$ Sum of bases; $\mathrm{T}=\mathrm{CEC}$ at $\mathrm{pH} 7 ; \mathrm{V}=$ base saturation; ${ }^{(1)} \mathrm{P}$ Mehlich 1 .

Source: Elaborated by the authors (2018).

The experiment was arranged in a randomized complete block design, in subdivided plots. The main plots consisted of three types of common bean (Carioca bean: Pérola, Black bean: IPR Tuiuiu, and Red bean: VR20) and the subplots of the different herbicides and mixtures, with four replications, in three growing seasons. The subplots consisted of a hand weeding treatment without herbicide and the others of the application of different herbicide mixtures (Table 2).

Table 2 - Common bean cultivars evaluated in the field in response to different treatments.

\begin{tabular}{lccc}
\hline \multirow{2}{*}{ Commercial product } & \multirow{2}{*}{ Active ingredient } & R.c (L.ha') & ai (g L) \\
\cline { 3 - 4 } & & - & - \\
\hline Hand weeding & - & 1 & 250 \\
Flex $^{\circledR}$ & fomesafem & 1,5 & 375 \\
\hline Flex & fomesafem & & (continuae...)
\end{tabular}


Table 2 - Continuation.

\begin{tabular}{lccc}
\hline \multirow{2}{*}{ Commercial product } & \multirow{2}{*}{ Active ingredient } & p.c (L.ha-1) & ai (g L) \\
\cline { 3 - 4 } & bentazon + imazamox & 1 & $600+28$ \\
Amplo $^{\circledR}$ & bentazon + imazamox + fomesafem & $1+0,5$ & $600+28+125$ \\
Amplo $^{\circledR}+$ Flex $^{\circledR}$ & bentazon + imazamox + fomesafem & $1+0,35$ & $600+28+83$ \\
Amplo $^{\circledR}+$ Flex $^{\circledR}$ & &
\end{tabular}

Source: Elaborated by the authors (2018).

Common bean was sown mechanically on November 10, 2016; July 21, 2017 and November 15, 2017, corresponding to the growing seasons 1,2 , and 3, respectively. Thirteen seeds per meter were planted in rows, spaced $0.6 \mathrm{~m}$ apart, for a plant density of 220,000 ha-1. In the 2016/2017 rainy crop season, the subplots consisted of six $10 \mathrm{~m}$ long rows, making a total area of $36 \mathrm{~m}^{2}$, and the plots composed of $648 \mathrm{~m}^{2}$. On the other hand, in the fall/winter 2017 and $2017 / 2018$ rainy crop season, each subplot consisted of six $6 \mathrm{~m}$ long rows, making a total area of $21,6 \mathrm{~m}^{2}$, and the plots were composed of $388,8 \mathrm{~m}^{2}$.

The seeds were treated with the fungicides carboxanilide + dimethyldithiocarbamate (VitavaxThiram $^{\circledR} 200+200 \mathrm{~g} \mathrm{ha}^{-1}$ of a.i.), at a rate of $250 \mathrm{~mL}$ per $100 \mathrm{~kg}$ seeds and with fungicides/ insecticide pyraclostrobin + thiophanate-methyl + fipronil (Standak Top ${ }^{\circledR}, 25+225+250 \mathrm{~g} \mathrm{ha}^{-1}$ of a.i.), at a rate of $200 \mathrm{~mL}$ per $100 \mathrm{~kg}$ seeds.

The fertilization recommended for common bean was applied as proposed by Souza and Lobato (2004). Fertilization at sowing consisted of $320 \mathrm{~kg} \mathrm{ha}^{-1}$ of the fertilizer NPK 8-28-16, resulting in 26; $90 ; 51 \mathrm{~kg} \mathrm{ha}^{-1}$ of $\mathrm{N}, \mathrm{P}_{2} \mathrm{O}_{5}$, and $\mathrm{K}_{2} \mathrm{O}$, respectively. When the crop reached the phenological stage $\mathrm{V} 3$ (first trifoliolate leaf), cobalt and molybdenum were applied by mechanical spraying. Subsequently, side dressing was applied, with $100 \mathrm{~kg} \mathrm{~N} \mathrm{ha}^{-1}$, with urea as the source.

The herbicides were applied at 26, 25, and 29 days after crop emergence in growing season 1 , 2 , and 3 respectively. At that time, cultivar Pérola and IPR Tuiuiu plants were in stage V4.4 (fourth trifoliate leaf) and cultivar VR20 in V4.3 (three trifoliate leaves). For the application of the treatments, a $\mathrm{CO}_{2}$ pressurized backpack sprayer with a syrup volume of $200 \mathrm{~L}$ ha-1 was equipped with a bar with four spray nozzles type DG 11002 that produced medium droplets at an average pressure of $200 \mathrm{kpa}$.

Hand weeding was performed only once with a hoe, on the same date as the herbicide application. To control the grass weeds in the area, fluazifop-p-butyl (Fusilade ${ }^{\circledR} 250 \mathrm{~g} \mathrm{ha}^{-1}$ of a.i.) at $1 \mathrm{~L} \mathrm{ha}^{-1}$ was applied across the experimental area, four days after treatment application (broadleaf herbicides) in all growing seasons.

At 7 and 14 days after herbicide application, the weed infestation level in each treatment was evaluated, by determining the number of weeds per species. To this end, the weeds contained within a square of $0.5 \mathrm{~m} \times 0.5 \mathrm{~m}$ were counted. The plant density per species (plant $\mathrm{m}^{-2}$ ) was determined and the relative density was calculated as the number of plants per species in relation to the total (in \%).

The phytotoxicity was evaluated according to the intoxication of the plants by a visual assessment of the damages in common bean, at 7 and 14 days after herbicide application. The scores were based on the mean of four replicates, attributed based on the grade scale, of the European Weed Research Council (EWRC), according to Melhorança (1984): 1: no damage; 2: small changes (discoloration, deformation) visible on some plants; 3: small changes (discoloration, deformation) on many plants; 4: strong discoloration (yellowing) or significant deformation, but no necrosis (tissue death); 5: necrosis (blackening) of some leaves, particularly on the edges, accompanied by leaf and shoot deformation; 
6: necrosis (deformation) on more than $50 \%$ of the leaves and shoots; 7 : more than $80 \%$ destroyed leaves and shoots; 8: extremely serious damage, leaving only minor green patches on the plants; 9: plant death.

In all experiments, grain yield was evaluated, based on the moisture content corrected to $13 \%$, in $\mathrm{kg} \mathrm{ha}^{-1}$. The data were subjected to individual analysis of variance for each experiment, to test the homogeneity of variance and, later, the combined analysis for the locations. The means were compared by the Scott-Knott test at $5 \%$ probability, using the statistical software SISVAR (FERREIRA, 2011).

\section{Results and discussion}

In the evaluations of weed control, the coefficient of variation was high (CV > 20\%) in all growing seasons (Table 3), as reported elsewhere (SILVA et al., 2014). The analysis of variance for weed control in the experimental area indicated significant differences $(p<0.05)$ among the herbicides applied and the cultivation environments at 7 and 14 days after application (DAA), in response to the control modes.

In growing season 1 (rainy season 2016/2017), all herbicides resulted in a control level similar to that of hand weeding (Table 3), except for herbicide bentazon+imazamox at the prescribed rate (1 L ha-1), as observed at 7 and 14 DAA. However, Machado et al. (2008) reported high efficacy in the control of Euphorbia heterophylla, Ipomea sp., Commelina benghalensis, and Bidens pilosa after bentazon+imazamox application at the full rate $\left(1 \mathrm{~L} \mathrm{ha}^{-1}\right)$.

Table 3 - Percentage of weed control (\%), as affected by weed control modes.

\begin{tabular}{|c|c|c|c|c|c|}
\hline \multirow{2}{*}{\multicolumn{3}{|c|}{ Control forms }} & \multicolumn{3}{|c|}{$7 \mathrm{DAA}^{1}$} \\
\hline & & & \multirow{2}{*}{$\begin{array}{c}\text { Rainy season }(16 / 17) \\
\text { imazamox }\end{array}$} & \multirow{2}{*}{$\begin{array}{c}\text { Autumn/ winter (2017) } \\
\text { fomesafem }\end{array}$} & \multirow{2}{*}{$\begin{array}{c}\text { Rainy seasor } \\
(17 / 18)\end{array}$} \\
\hline bentazon & imazamox & fomesafem & & & \\
\hline \multicolumn{3}{|c|}{ 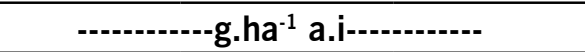 } & \multicolumn{3}{|c|}{ - } \\
\hline \multicolumn{3}{|c|}{ No herbicides (weeding) } & $100 \mathrm{aA}$ & $100 \mathrm{aA}$ & $100 \mathrm{aA}$ \\
\hline _ & - & 250 & $92 \mathrm{aA}$ & $58 \mathrm{bB}$ & $57 \mathrm{bB}$ \\
\hline- & - & 375 & 94 aA & 75 aA & 67 \\
\hline 600 & 28 & - & $43 \mathrm{bA}$ & $58 \mathrm{bA}$ & 42 \\
\hline 600 & 28 & 125 & $87 \mathrm{aA}$ & 75 aA & 82 \\
\hline 600 & 28 & 83 & $81 \mathrm{aA}$ & $83 \mathrm{aA}$ & 60 \\
\hline \multicolumn{3}{|c|}{ C.V.1 (\%) } & 37,56 & & \\
\hline \multicolumn{2}{|c|}{ C.V.2 (\%) } & & 38,96 & & \\
\hline & & & & 14 DAA & \\
\hline \multicolumn{3}{|c|}{ 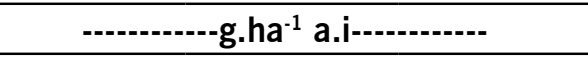 } & \multicolumn{3}{|c|}{ - - } \\
\hline \multicolumn{3}{|c|}{ No herbicides (weeding) } & $100 \mathrm{aA}$ & $100 \mathrm{aA}$ & $100 \mathrm{aA}$ \\
\hline - & _ & 250 & $84 \mathrm{aA}$ & $42 \mathrm{bB}$ & $14 \mathrm{bB}$ \\
\hline - & - & 375 & $92 \mathrm{aA}$ & $60 \mathrm{bB}$ & 30 \\
\hline 600 & 28 & - & $53 \mathrm{bA}$ & $49 \mathrm{bA}$ & 23 \\
\hline 600 & 28 & 125 & $92 \mathrm{aA}$ & $53 \mathrm{bB}$ & 49 \\
\hline 600 & 28 & 83 & $85 \quad a A$ & $50 \mathrm{bB}$ & 16 \\
\hline \multicolumn{3}{|c|}{ C.V.1 (\%) } & 69,1 & & \\
\hline \multicolumn{2}{|c|}{ C.V.2 (\%) } & & 50,4 & & \\
\hline
\end{tabular}

Means followed by the same lowercase letter in a column and upper case in a row do not differ from each other statistically by the Scott-Knott test at $5 \%$ probability.

Note. ${ }^{1}$ DAA: days after application.

Source: Elaborated by the authors (2018). 
The low control efficacy of bentazon+imazamox in the first growing season may be related to the irregular weed occurrence in the experimental plots and to the presence of Bidens pilosa (hairy beggartick) and Alternanthera tenella (joyweed) and in a larger population in the total area (Table 4).

Table 4 - Percentage of weeds in the total area on day 0 before the application of weed control, in growing seasons 1 and 2 (2016/17) and growing season 3 (2017/18).

\begin{tabular}{|c|c|}
\hline \multicolumn{2}{|c|}{ Rainy season $2016 / 17$} \\
\hline Bidens pilosa & $56 \%$ \\
\hline Alternanthera tenella & $28 \%$ \\
\hline Galinsoga parviflora & $8 \%$ \\
\hline Others & $5 \%$ \\
\hline Commelina benghalensis & $3 \%$ \\
\hline \multicolumn{2}{|c|}{ Autumn/winter 2017} \\
\hline Commelina benghalensis & $36 \%$ \\
\hline Ipomoea triloba & $31 \%$ \\
\hline Richardia brasiliensis & $14 \%$ \\
\hline Amaranthus retroflexus & $10 \%$ \\
\hline Others & $9 \%$ \\
\hline \multicolumn{2}{|c|}{ Rainy season $2017 / 18$} \\
\hline Commelina benghalensis & $29 \%$ \\
\hline Alternanthera tenella & $21 \%$ \\
\hline Blainvillea dichotoma & $18 \%$ \\
\hline Ipomoea triloba & $17 \%$ \\
\hline Others & $15 \%$ \\
\hline
\end{tabular}

Source: Elaborated by the authors (2018).

Although bentazon+imazamox is recommended for the control of Bidens pilosa (hairy beggartick), in this case, the control was inadequate due to the high infestation with this weed in the area. The data of the weed control level observed here differed from those presented by Marchioretto and Magro (2017). These authors stated an efficient control of Bidens pilosa with imazamox (30 $\mathrm{g} \mathrm{ha}^{-1}$ ), blended or sequentially applied with bentazon (480 $\mathrm{g} \mathrm{ha}^{-1}$ ), or by applying fomesafen (125 $\mathrm{g} \mathrm{ha}^{-1}$ ), although an antagonistic effect of the mixture or the sequential application was observed. On the other hand, Nicolai et al. (2006) do not recommend the use of ALS-inhibiting herbicides for the control of resistant biotypes of Bidens pilosa and Bidens subalternans. However, the characteristic of ALS resistance in Bidens pilosa was not evaluated or proven in this study anyway.

In the case of Alternanthera tenella, although germination is more intense in the presence of light, it can also germinate in the dark, causing the species to emerge later in the cycle of summer crops, hampering an effective control (CANOSSA et al., 2008).

On the other hand, in growing season 2 (autumn/winter 2016/17), bentazon+imazamox and fomesafem, demonstrating the low efficacy of herbicides when applied separately, 7 DAA. However, when applied together ( $1 \mathrm{~L} \mathrm{ha}^{-1}$ bentazon+imazamox $+0.5 \mathrm{~L} \mathrm{ha}^{-1}$ fomesafem) the control efficacy was adequate. After 14 days, herbicide proved less efficient than hand weeding. This was due to the high infestation with traboeraba (Commelina benghalensis) (TABLE 4), for which the herbicides, although recommended for this species, could not efficiently control it; apart from the fact that other weed species germinated, after the last evaluation.

In growing season 3 (rainy season 2017/2018), the control of the herbicide mixture of bentazon+imazamox (1 L ha-1 ha $\left.{ }^{-1}\right)+$ fomesafem $\left(0.5 \mathrm{~L} \mathrm{ha}^{-1}\right)$ was significant, similar to that of hand 
weeding (100 \% weed-free). However, after 14 days, the control of this treatment tended to be better than the others, with a $28.1 \%$ higher efficacy than when using $1 \mathrm{~L} \mathrm{ha}^{-1}$ fomesafem. However, at 14 days, no significant difference compared to the control (hand weeding) was observed. This fact can be explained by the emergence of new weed species in the experimental area.

According to Silva et al. (2013), the blend of fomesafen + bentazon + imazamox allows a reduction in fomesafen rates by up to $1 / 4$, resulting in excellent weed control and easy conditions of bean harvesting, as well as reducing the residual risk for sorghum and corn. Regarding the evaluation of phytotoxicity, no symptoms were observed after the products were applied, proving the control efficacy of the herbicides regarding the three bean cultivars.

Linhares et al. (2014) concluded that the mixture bentazon + imazamox does not alter the growth characteristics of common bean plants, for being selective. Also, concerning phytotoxicity, Galon et al. (2017) reported that the herbicides fomesafen, bentazon, or the commercial blend bentazon + imazamox caused some lesions on the black bean cultivar BRS Campeiro. However, the plants recovered quickly from the injuries and the subsequent development was not affected.

According to the analysis of variance for grain yield data, the experimental precision was good (CV $15.6 \%$ ). The yields differed according to the cultivars, control modes, and growing seasons. By partitioning the triple interaction, the effect of the herbicides on each bean cultivar could be studied, and their behavior within each cultivation environment (growing season) assessed (TABLE 5). Therefore, the same treatment results in different responses in control efficiency when applied in different environments, since the efficacy of a herbicide or herbicide mixture for weed control can vary according to the weed community and environmental factors.

Table 5 - Average triplex of the outspread of application control modes (herbicides trials) within the crop and cultivars for common bean grain yield in kg. ha- ${ }^{-1}$.

\begin{tabular}{|c|c|c|c|c|c|c|}
\hline \multicolumn{7}{|c|}{ Herbicides $(\mathrm{H})$} \\
\hline C-A & Weeding & $\begin{array}{l}\text { fomesafem } \\
\text { (250 g i.a) }\end{array}$ & $\begin{array}{l}\text { fomesafem } \\
\text { (375 g i.a) }\end{array}$ & $\begin{array}{c}\text { bentazon }+ \\
\text { imazamox } \\
(600+28 \mathrm{~g} \text { i.a })\end{array}$ & $\begin{array}{c}\text { bentazon+ } \\
\text { imazamox }+ \\
\text { fomesafem } \\
(600+28+ \\
125 \text { g i.a) }\end{array}$ & $\begin{array}{c}\text { bentazon }+ \\
\text { imazamox }+ \\
\text { fomesafem } \\
(600+28+ \\
83 \text { g i.a) }\end{array}$ \\
\hline Pérola- 1 & $2280 \mathrm{a}$ & $2220 \mathrm{a}$ & $2220 \mathrm{a}$ & $2040 \mathrm{a}$ & $2460 \mathrm{a}$ & $2460 \mathrm{a}$ \\
\hline Pérola- 2 & 1020 a & $1140 \mathrm{a}$ & 1320 a & 1080 a & 1320 a & 1020 a \\
\hline Pérola- 3 & $1740 \mathrm{a}$ & $1260 \mathrm{~b}$ & $1020 \mathrm{~b}$ & $1080 \mathrm{~b}$ & $1680 \mathrm{a}$ & $1260 \mathrm{~b}$ \\
\hline IPR Tuiuiu-1 & $2160 c$ & $3000 \mathrm{a}$ & $3240 \mathrm{a}$ & $2640 \mathrm{~b}$ & $2940 \mathrm{a}$ & $3360 \mathrm{a}$ \\
\hline IPR Tuiuiu-2 & $1380 \mathrm{~b}$ & $1680 a$ & $1320 \mathrm{~b}$ & $1440 \mathrm{~b}$ & $1860 \mathrm{a}$ & $1860 \mathrm{a}$ \\
\hline IPR Tuiuiu-3 & $1500 a$ & $1560 a$ & 1560 a & 1320 a & $1320 a$ & $1200 a$ \\
\hline VR 20-1 & $2160 \mathrm{~b}$ & $2280 \mathrm{~b}$ & $2940 a$ & $2940 a$ & $2580 a$ & $2760 \mathrm{a}$ \\
\hline VR 20-2 & $1260 \mathrm{a}$ & $1440 \mathrm{a}$ & $1500 \mathrm{a}$ & $1260 \mathrm{a}$ & $1020 \mathrm{a}$ & $1260 \mathrm{a}$ \\
\hline VR 20-3 & $2340 \mathrm{a}$ & $2220 \mathrm{a}$ & $2460 \mathrm{a}$ & $2220 \mathrm{a}$ & $2280 \mathrm{a}$ & $2220 \mathrm{a}$ \\
\hline Média - H & 1760 & 1867 & 1953 & 1780 & 1940 & 1933 \\
\hline \multicolumn{2}{|c|}{ C.V.1 (\%) } & & 15,7 & & & \\
\hline \multicolumn{2}{|c|}{ C.V.2 (\%) } & & 15,6 & & & \\
\hline
\end{tabular}

Means followed by the same letter on the lines, do not differ statistically from each other by the Scott-Knott test at $5 \%$ probability.

Note. 1: rainy season 2016/2017. 2: autumn/winter (2016/17). 3: rainy season (2017/18).

Source: Elaborated by the authors (2018). 
In the first growing season (rainy season 2016/2017), there was no effect of the control modes on common bean yield of cultivar Pérola (TABLE 5). However, the yield of cultivar IPR Tuiuiu was reduced when bentazon+imazamox $\left(1 \mathrm{~L} \mathrm{ha}^{-1}\right)$ was applied and by hand weeding. This result differs from that reported by Galon et al. (2017), who observed similar yields to the control for black beans.

The low yield in this treatment (TABLE 5) can be attributed to the lower efficacy of bentazon + imazamox, observed in this study, in controlling weeds in the first growing season (2016/2017). Although hand weeding controlled the weeds by $100 \%$, the yield reduction can be explained by the germination of weed species, after the last evaluation at 14 days, which did not occur in the study of Galon et al. (2017).

The yields of cultivar VR20 were lowest in the plots where hand weed control (weeding) and control with $1 \mathrm{~L} \mathrm{ha}^{-1}$ fomesafem were performed. This fact can be attributed to the germination of new weed species in the area, after the evaluation 14 days after chemical weeding, as well as at the location of fomesafem application, since these control modes leave no residues in the soil.

In growing season 2 (autumn/winter 2016/2017) however, no effect of the control modes on cultivars Pérola and bean lineage VR20 was observed. Nevertheless, for cultivar IPR Tuiuiu, the mean yields were lowest when treated with hand weeding and application of $1 \mathrm{~L}$ ha-1 bentazon+imazamox and $1.5 \mathrm{~L} \mathrm{ha}^{-1}$ fomesafem. Although the efficacy of hand weeding was effective up to 14 DAA (TABLE 3 ), the efficiency of this practice was not evaluated after 14 DAA. As this method leaves no residues, weeds that possibly occurred after 14 DAA may have affected the common bean yield negatively. In the case of cultivar IPR Tuiuiu, grown in the plots treated with $1 \mathrm{~L} \mathrm{ha}^{-1}$ bentazon+imazamox, it is believed that the lower efficacy in weed control may have affected common bean yields.

Regarding fomesafem at $1.5 \mathrm{~L} \mathrm{ha}^{-1}$, although it controlled weeds efficiently (TABLE 3 ) and no phytotoxicity symptoms on the bean plants were visually detectable, there may have been some hidden phytotoxicity in the plants of cultivar IPR Tuiuiu, resulting in the lowest yields. According to Cieslik, Vidal and Trezzi (2014), a possible explanation for the recovery of common bean plants from herbicide symptoms is that the herbicide does not move from the sprayed tissue to the new shoots as well as the action of the enzymes glutathione S-transferase (GST), which detoxify the herbicides.

Although in this study only the yield of cultivar IPR Tuiuiu was affected by the different herbicides, yield losses due to weeds are common. In studies with carioca bean, the common bean yield was reduced by $67 \%$, in a comparison of the yield produced in a total absence of weeds (completely weed-free - $2516 \mathrm{~kg} \mathrm{ha}^{-1}$ ) with that produced in the presence of some weeds during the entire cycle (partially weed-free environment - $1095 \mathrm{~kg} \mathrm{ha}^{-1}$ ) (SALGADO et al., 2007). As a result of weed interference, Vogt et al. (2013) reported yield losses in black bean cultivars from 30.8 \% to $54.9 \%$. For cultivar IPR Tuiuiú, Galon et al. (2016) observed a productivity decrease of approximately $30 \%$ at 41 days after emergence, when up to $10 \%$ of weed cover was maintained.

Interestingly, the common bean yield was lower in the winter than in the other seasons. This was unexpected because the crop was planted in a central pivot area, in which common bean yields tend to be very high. However, in this area, the seasonally low temperatures possibly affected crop productivity negatively.

In growing season 3, Pérola produced a higher yield when treated with hand weeding and the mixture of bentazon + imazamox $\left(1 \mathrm{~L} \mathrm{ha}^{-1}\right)+$ fomesafem $\left(0.5 \mathrm{~L} \mathrm{ha}^{-1}\right.$ ) (rainy season 2017/2018). In a study by Marchioretto and Magro (2017), the highest yields were also achieved when fomesafen herbicides were combined with the commercial mixture bentazon with imazamox. This can be explained by the higher level of weed control in the area of these two treatments than in the others, 
which reduced weed competition and improved productivity. The cultivars IPR Tuiuiu and bean lineage VR20 did not respond to the different weed control modes.

It is worth mentioning that the prescribed rate of fomesafem $\left(\mathrm{Flex}^{\circledR}\right)$ for weed control in common bean ( $1 \mathrm{~L} \mathrm{ha}^{-1}$ ), independently of the cultivar, causes some delay in crop growth, as described by Linhares et al. (2014). The only mixture officially recommended for chemical weed control in common bean was bentazon + imazamox $\left(\right.$ Amplo $\left.^{\circledR}\right)$, which is a commercial product for broadleaf weed control. The other blends were tested because they are commonly used by the producers. Currently, after the approval of law 6299/02 that allows herbicide mixtures in tanks, all blends tested here may be used.

\section{Conclusions}

Separate applications of Flex ${ }^{\circledR} 1 \mathrm{~L} \mathrm{ha}^{-1}$ (fomesafen) and the mixture of Amplo ${ }^{\circledR}+$ Flex ${ }^{\circledR}$ blends (imazamox + bentazon + fomesafen) control weeds efficiently.

The separate and mixed applications of the herbicides have no phytotoxicity effects on any of the studied common bean cultivars.

\section{Acknowledgements}

To Conselho Nacional de Desenvolvimento Científico e Tecnológico (CNPq), for supporting this research.

\section{Eficácia da mistura em tanque de herbicidas pós- emergentes em diferentes cultivares de feijão-comum}

\section{Resumo}

Na cultura do feijoeiro, a ocorrência de plantas daninhas pode causar grandes reduções no rendimento final dos grãos. Este trabalho teve como objetivo avaliar a eficácia de diferentes herbicidas, aplicados de forma isolada ou em mistura, no manejo de plantas daninhas na cultura do feijoeiro-comum. O delineamento estatístico adotado foi blocos casualizados, no esquema de parcelas subdivididas. As parcelas principais foram constituídas por três cultivares de feijão (cultivar Carioca Pérola, cultivar do grupo preto IPR Tuiuiu e cultivar do grupo vermelho Ouro VermelhoVR20) e as subparcelas pelos diferentes modos de controle, com quatro repetições: capina manual, fomesafem (250 $\mathrm{g} \mathrm{ha}^{-1}$ de ingrediente ativo (i.a.)), fomesafem (375 $\mathrm{g} \mathrm{ha}^{-1}$ de i.a.), imazamox + bentazon $(0,23+0,6 \mathrm{~g}$ ha-1 de i.a.), imazamox + bentazon + fomesafem $\left(0,23+0,6+125 \mathrm{~g}^{-1}\right.$ ha ${ }^{-1}$ i.a. $)$ e imazamox + bentazon + fomesafem $\left(0,23+0,6+83 \mathrm{~g} \mathrm{ha}^{-1}\right.$ de i.a. $)$. Avaliaram-se durante três safras plantas daninhas presentes na área, sintomas de fitotoxicidade e produtividade do feijoeiro. Os dados foram submetidos à análise de variância (Teste F) e as médias obtidas foram agrupadas pelo teste ScottKnott a $5 \%$ de probabilidade. Verificaram-se diferenças na produtividade de grãos, sendo observadas entre cultivares e safras devido à aplicação dos herbicidas. O tratamento mais eficaz foi imazamox + bentazon + fomesafem $\left(230+600+125 \mathrm{~g} \mathrm{ha}^{-1}\right.$ de i.a. $)$, resultando no melhor controle de plantas daninhas e maior eficiência na produtividade final dos grãos.

Palavras-chave: Controle químico. Phaseolus vulgaris. Produtividade. Fitotoxicidade. Plantas daninhas. 


\section{References}

BARCELlOS JUNIOR, L. H.; PEREIRA, G. A. M.; CAPOBIANGO, N. P.; SILVA, D. V.; BRAGA, R. R.; FERRIERA, E. A. Phytosociology of weeds in bean crops with different herbicides control. Revista Brasileira de Herbicidas, Londrina, v. 15, n. 3, p. 221-231, 2016. Available at: http://dx.doi.org/10.7824/rbh. v15i3.479. Access on: 07 mar. 2019.

BORCHARTT, L.; JAKELAITIS, A.; VALADÃO, F. C. A.; VENTUROSO, L. A. C.; SANTOS, C. L. Períodos de interferência de plantas daninhas na cultura do feijoeiro-comum (Phaseolus vulgaris L.). Revista Ciência Agronômica, Fortaleza, v. 42, n. 3, p. 725-734, 2011. Available at: http://ccarevista.ufc.br/ seer/index.php/ccarevista/article/view/1176. Access on: 07 mar. 2019.

BRESSANIN, F. N.; GIANCOTTI, P. R. F.; JAYME NETO, N.; AMARAL, C. L.; ALVES, P. L. C. A. Eficácia de herbicidas aplicados isolados em pré e pós-emergência no controle de mucuna-preta. Revista Brasileirade Ciências Agrárias, Recife, v. 10, n. 3, p. 426-431, 2015. Available at: https://doi.org/ 10.5039 /agraria.v10i3a5337. Access on: $1^{\circ}$ mar. 2019.

CANOSSA, R. S.; OLIVEIRA JR., R. S.; CONSTANTIN, J.; BRACCINI, A. L.; BIFFE, D. F.; ALONSO, D. G.; BLAINSKI, E. Temperatura e luz na germinação das sementes de apaga-fogo (Alternanthera tenella). Planta Daninha, Viçosa, v. 26, n. 4, p. 745-750, 2008. Available at: https://doi.org/10.1590/ S0100-83582008000400005. Access on: 07 mar. 2019.

CIESLIK, L. F.; VIDAL, R. A.; TREZZI, M. M. Fomesafen toxicity to bean plants as a function of the time of application and herbicide dose. Acta Scientiarum - Agronomy, Maringá, v. 36, n. 3, p. 329-334, 2014. Available at: https://doi.org/10.4025/actasciagron.v36i3.17630. Access on: 10 jan. 2019.

FERREIRA, D. F. Sisvar, a computer statistical analysis system. Ciência e Agrotecnologia, Lavras, v. 35, n. 6, p. 1039-1042, 2011. Available at: https://doi.org/10.1590/S1413-70542011000600001. Access on: 03 apr. 2019.

FREITAS, F. C. L.; MEDEIROS, V. F. L. P.; GRANGEIRO, L. C.; SILVA, M. G. O.; NASCIMENTO, P. G. M. L.; NUNES, G. H. Interferência de plantas daninhas na cultura do feijão-caupi. Planta Daninha, Viçosa, v. 27, n. 2, p. 241-247, 2009. Available at: https://doi.org/10.1590/S010083582009000200005. Access on: 07 mar. 2019.

GALON, L.; FORTE, C. T.; GABIATTI, R. L.; RADUNZ, L. L.; ASPIAZÚ, I.; KUJAWINSKI, R.; DAVID, F. A.; CASTOLDI, C. T.; PERIN, G. F.; RADUNZ, A. L.; ROSSETTI, J. Interference and economic threshold level for control of beggartick on bean cultivars. Planta Daninha, Viçosa, v. 34, n. 3, p. 411-422, 2016.Available at: https://doi.org/10.1590/s0100-83582016340300002. Access on: 10 jan. 2019.

GALON, L.; WINTER, F. L.; FORTE, C. T.; AGAZZI, L. R.; BASSO, F. J. M.; HOLZ, C. M.; PERIN, G. F. Associação de herbicidas para o controle de plantas daninhas em feijão do tipo preto. Revista Brasileira de Herbicidas, Londrina, v. 16, n. 4, p. 268-278, 2017. Available at: https://doi.org/10.7824/rbh. v16i4.559. Access on: 10 jan. 2019. 
INSTITUTO NACIONAL DE METEOROLOGIA - INMET. Estações Convencionais - Gráficos. (2018). Available at: http://www.inmet.gov.br/portal/index.php?r=home/page\&page=rede_estacoes_conv_ graf. Access on: 07 jul. 2019.

LAMEGO, F. P.; BASSO, C. J.; VIDAL, R. A.; TREZZI, M. M.; SANTI, A. L.; RUCHEL, Q.; KASPARY, T. E.; GALLON, M. Seletividade Dos Herbicidas S-Metolachlor e Alachlor para o Feijão-Carioca. Planta Daninha,Viçosa, v. 29, n. 4, p. 877-883, 2011. Available at: https://dx.doi.org/10.1590/S010083582011000400018 . Access on: 10 jan. 2019.

LINHARES, C. M. S.; FREITAS, F. C. L.; SILVA, K. S.; LIMA, M. F. P.; DOMBROSKI, J. L. D. Crescimento do feijão-caupi sob efeito dos herbicidas fomesafen e bentazon+imazamox. Revista Caatinga, Mossoró, v. 27, n. 1, p. 41-49, 2014. Available at: https://periodicos.ufersa.edu.br/index. php/caatinga/article/view/2572/pdf_84. Access on: 10 jan. 2019.

MACHADO, A. A.; NASCENTE, A. S.; COBUCCI, T.; OlIVEIRA, K. G. B.; PEREIRA FILHO, C. R.; CARVAlHO, A. B. A.; CORRÊA, G. C. Avaliação da Eficiência de Controle de Plantas Daninhas do Herbicida Amplo e seu efeito na Produtividade do Feijoeiro Comum. Documentos, IAC, v. 85, p. 1376-1379, 2008. Available at: https://www.alice.cnptia.embrapa.br/bitstream/doc/945776/1/ machado.pdf. Access on: 07 mar. 2019.

MANABE, P. M. S.; MATOS, C. C.; FERREIRA, E. A.; SILVA, A. F.; SILVA, A. A.; SEDIYAMA, T.; MANABE, A.; ROCHA, P. R. R.; SILVA, C. T. Efeito da competição de plantas daninhas na cultura do feijoeiro. Bioscience Journal, Uberlândia, v. 31, n. 2, p. 333-343, 2015. Available at: https://www. embrapa.br/busca-de-publicacoes/-/publicacao/213300/manejo-de-plantas-daninhas-na-cultura-dofeijoeiro-em-plantio-direto. Access on: 10 jan. 2019.

MANCUSO, M. A. C.; AIRES, B. C.; NEGRISOLI, E.; CORREAA, M. R.; SORATTO, R. P. Seletividade e eficiência de herbicidas no controle de plantas daninhas na cultura do feijão-caupi. Revista Ceres, Viçosa, v. 63, n. 1, p. 25-32, 2016. Available at: https://dx.doi.org/10.1590/0034737X201663010004. Access on: 10 jan. 2019.

MARCHIORETTO, L. R.; MAGRO, T. D. Weed control and crop selectivity of post-emergence herbicides in common beans. Ciência Rural, Santa Maria, v. 47, n. 3, p. 1-6, 2017. Available at: https: //doi. org/10.1590/0103-8478cr20160295. Access on: 10 jan. 2019.

MELHORANÇA, A. L. Efeito dos herbicidas pós-emergentes no desenvolvimento e na produção de grãos de soja. Documento 7, Londrina: Embrapa-CNPSo, 1984. p.1078

NICOLAI, M.; CHRISTOFFOLETI, P. J.; MOREIRA, M. S.; CARVALHO, S. J. P.; TOLEDO, R.; SCARPARI, L. Alternativas de manejo para as populações de picão-preto (Bidens pilosa e Bidens subalternans) resistentes aos herbicidas inibidores da ALS. Revista Brasileira de Herbicidas, Passo Fundo, v. 5, n. 3, p. 72-79, 2006. Available at: https://doi.org/10.7824/rbh.v5i3.3. Access on: $1^{\circ}$ mar. 2019.

OLIVEIRA, M.B.; ALVES, P.F.S.; TEIXEIRA, M.F.F.; SILVA, H.D.; SÁ, R.A.; CAMPOS, R.G.C.; CARVALHO, A.J.; ASPIAZÚ, I. Fitotoxicidade de herbicidas aplicados em diferentes épocas em pósemergência do feijão-caupi. Unimontes Científica, Montes Claros, v. 15, n. 1, p. 64-70, 2013. 
Available at: https://www.periodicos.unimontes.br/index.php/unicientifica/article/view/2092/2181. Access on: $1^{\circ}$ mar. 2019.

SALGADO, T.P.; SALLES, M.S.; MARTINS, J.V.F.; ALVES, P.L.C.A. Interferência das plantas daninhas no feijoeiro Carioca. Planta Daninha, Viçosa, v. 25, n. 3, p. 443-448, 2007. Available at: https://doi.org/ 10.1590/S0100-83582007000300002. Access on: 10 jan. 2019.

SILVA, K.S.; FREITAS, F.C.L; SILVEIRA, L.M.; LINHARES, C.S.; CARVALHO, D.R.; LIMA, M.F.P. Eficiência de herbicidas para a cultura do Feijão-Caupi. Planta Daninha, Viçosa, v. 32, n. 1, p. 197-205, 2014. Available at: http://dx.doi.org/10.1590/S0100-83582014000100022 . Access on: 10 jan. 2019.

SILVA, V. P.; FERREIRA, L. R.; D'ANTONINO, L.; CARNEIRO, J.E.; SILVA, G. R.; FONTES, D. R. Eficiência e residual no solo de herbicidas na cultura do feijão. Planta Daninha, Viçosa, v. 31, n. 4, p. 961-970, 2013. Available at: https://dx.doi.org/10.1590/S0100-83582013000400022. Access on: 10 jan. 2019.

SISTEMA DE AGROTOXICOS FITOSSANITARIOS (AGROFIT). Consulta de Produtos Formulados. Available at: http://agrofit.agricultura.gov.br/agrofit_cons/principal_agrofit_cons. Access on: 08 apr. 2018.

SOUZA, D. M. G.; LOBATO, E. Cerrado: Correção do solo e adubação. Embrapa Cerrado. Brasília. 2004. 2. ed. p. 295-297.

VOGT, G. A.; JUNIOR, A. A. B.; TREZZI, M. M.; BACKES, R. L.; NICKNICH, W. Competitive ability of black common bean genotypes with weeds. Ciência e Agrotecnologia, Lavras, v. 37, n. 5, p. 397-403, 2013. Available at: https://dx.doi.org/10.1590/S1413-70542013000500002. Access on: 10 jan. 2019.

WEED SCIENCE INTERNATIONAL SURVEY OF HERBICIDE RESISTANT WEEDS (WEED). Available at: http://www.weedscience.org/Summary/SOADescription.aspx. Access on: 20 apr. 2020.

Submitted: July 26, 2020

Accepted: September 14, 2020 